\section{ENERGY CONSERVATION USING VARIABLE FREQUENCY DRIVES FOR CENTER-PIVOT IRRIGATION SYSTEMS EQUIPPED WITH CORNER WATERING ATTACHMENTS}

\author{
D. Brar, W. L. Kranz, T. Lo, S. Irmak, D. L. Martin
}

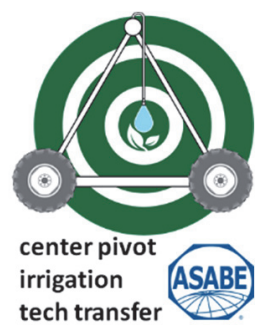

Collection

\begin{abstract}
HighLIGHTS
- Variable-frequency drives are suited to field sites with significant topographic features and corner attachments. - Variable-frequency drives conserve energy and lower operating cost for center pivots with corner attachments.

- Center pivots with corner extensions plus end guns resulted in an average payback period of less than ten years.
\end{abstract}

\begin{abstract}
Corner watering attachments, specifically end guns and corner extensions, attached to center-pivot systems are a common means to irrigate the corners of square fields. The pumping plant is designed to supply water to all sprinklers when the center pivot is irrigating the point of maximum elevation. Most designs include powering the irrigation pump at a fixed speed, which can lead to excessive energy use. Variable-frequency drives (VFDs) were introduced to adjust the pump speed in response to changes in pressure requirements. In this study, three scenarios were analyzed: scenario 1, end gun attached at end of centerpivot lateral; scenario 2, corner extension attached at end of center-pivot lateral; and scenario 3, corner extension attached at end of center-pivot lateral and end gun attached at the end of the corner extension. This study was conducted on 1000 randomly selected center-pivot irrigation systems located in ten counties of Nebraska using GIS-based tools. High-resolution digital elevation maps were used to investigate the impact of flow rate changes and topographical variations on energy requirements. Reductions in the energy required, obtained through varying the pump speed, and annual monetary savings were calculated for each scenario. Average payback periods for VFDs were calculated for each county. The major factors contributing to energy savings and annual returns include large topographical changes, duration of corner attachment operation, hours of operation, and electricity cost. Scenario 3 resulted in the maximum energy reduction, maximum annual monetary savings, and minimum payback period compared to the other scenarios. This approach allows investigation of the potential savings associated with installation of a VFD for center pivots equipped with end guns and corner arm extensions.
\end{abstract}

Keywords. Center-pivot irrigation systems, Corner watering attachments, End gun, Energy savings, GIS, Pumping, Topography, Variable-frequency drive.

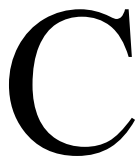

enter-pivot irrigation is one of the most widely used irrigation methods in the U.S. In Nebraska alone, about 55,000 center-pivot systems irrigate approximately 3.0 million ha (USDA-NASS, 2014). Center pivots are popular due to their suitability for different field to-

\footnotetext{
(c) $(9)$ The authors have paid for open access for this article. This work is licensed under a Creative Commons AttributionNonCommercial-NoDerivatives 4.0 International License https://creative commons.org/licenses/by-nc-nd/4.0/

Submitted for review in January 2019 as manuscript number NRES 13312; approved for publication as part of the Center-Pivot Irrigation Tech Transfer Collection by the Natural Resources \& Environmental Systems Community of ASABE in July 2019.

The authors are Dilshad Brar, Former Graduate Student, William L. Kranz, Professor, Tsz Him Lo, Graduate Student, Suat Irmak, Distinguished Professor, and Derrel L. Martin, Professor, Department of Biological Systems Engineering, University of Nebraska, Lincoln, Nebraska. Corresponding author: William L. Kranz, Haskell Agricultural Laboratory, 57905866 Road, Concord, NE 68728; phone: 402-584-3857; e-mail: wkranz1@unl.edu.
}

pographies, ease of management, and potential for high application efficiency. However, because most fields are square or rectangular, a disadvantage of center piv-ots is that they leave some areas unirrigated in the corners (Von Bernuth, 1983). A center-pivot system with no corner attachments can irrigate approximately $78.5 \%$ of a square field. With the addition of an end gun, the irrigated area increases to $88 \%$ of the square. The addition of corner extensions increases the irrigated area to $95 \%$ or more depending on whether an end gun is operated at the end of the corner extension.

An end gun is a single large sprinkler attached at the end of the pivot lateral that is designed to operate only in the corners of the field. Advantages of end guns are that they increase the irrigated area, and they are relatively inexpensive (Scaloppi and Allen, 1993a). Different kinds of end guns are available with varying flow rates, wetted diameters, and operating pressures. Some disadvantages of end guns are that they require relatively high pressure to distribute water, they change the flow rate that must be delivered by the pumping plant, and they typically deliver water with a lower application uniformity. To address the 
pressure requirement, center pivots are often equipped with booster pumps to increase the pressure delivered to the end gun (Scaloppi and Allen, 1993b).

A corner extension, which consists of a section of pivot lateral attached at the distal end of the center pivot, allows the center pivot to irrigate field corners. Although a different number of drive towers can be present, in this study we refer to the main part of a center pivot as a "standard" system with seven towers. Each drive tower follows a circular path, and the corner extensions follow a buried cable or another guidance system, such as GPS navigators, that causes the corner extension to extend into the corner of the field and then retract behind the main part of the system as the center pivot departs from the corner. Corner extensions increase the center-pivot length to irrigate an additional 2.75 ha or more at each corner (Davis et al., 1986). The major advantage of corner extensions is that they allow growers to irrigate more acres without buying more land or purchasing additional center-pivot systems. Along with these benefits, corner extensions require greater capital investment for the corner extension lateral, greater horsepower to meet increased pressure requirements, and greater costs for control and potential maintenance.

Irrigation of a greater portion of the field corners requires installation of an end gun at the distal end of the corner extension. End gun operation initiates when the corner attachment is nearing full extension (typically $9^{\circ}$ in each corner), further increasing the area irrigated. The effective radius of the end gun determines the area irrigated with optimum application depth. Manufacturer-listed radii establish the angle of operation to ensure that all the water is applied within the field boundaries.

The flow rate in a corner extension varies as the corner extension extends and retracts and is controlled by hydraulic valves installed at each sprinkler on the corner extension. As the corner extension extends, additional sprinklers turn on. As the extension retracts from the corner, sprinklers shut off according to the degree of extension and retraction. All the sprinklers are in operation when the corner extension is fully extended into a corner of the field. When fully extended, the flow rate is the combination of the flow required by the standard system, by the corner extension, and by the end gun if the system is equipped with an end gun.

Attachment of corner extensions to standard systems increases the flow rate and pipeline friction loss in the pivot lateral. The end gun flow rate is generally about $15 \%$ of the standard system flow rate depending on the design area of coverage (Buttermore and Eisenhauer, 1989). Use of corner extensions and end guns affects the performance of the pump impeller by shifting the operating point on the pump characteristic curve. If properly selected, the pump impeller should operate at maximum efficiency with the corner extension fully extended and the end gun in operation. The increase in pivot flow rate reduces the pressure at a pivot point as the impeller operation moves to the right on the pump curve (Von Bernuth, 1977; Edling, 1982).

Although corner attachments can irrigate additional area, the increased flow rate and friction loss lead to greater energy consumption. The design criteria for a center-pivot system equipped with an end gun or corner extension are when the pivot is at the greatest elevation in the field and the end gun or corner extension is in full operation. As mentioned by Brar et al. (2017), the design conditions are not applicable at all times and do not remain the same when the end gun or corner extension turns off or when the pivot moves downhill. If the pump operates at a constant speed while turning the corner attachments on and off, the operating point on the pump performance curve shifts to the right, making its operation less efficient.

Von Bernuth (1977) suggested that an increase in pump speed could compensate for the pressure drop at the pivot point due to operation of an end gun. A relatively new technology in the irrigation industry is variable-frequency drives (VFDs). VFDs can increase or decrease the speed of an electric motor according to the required conditions, as explained by Brar et al. (2017). VFDs can assist in achieving the minimum required pressure for any field condition (elevation difference, end gun or corner extension operation) as the pivot rotates, instead of setting a single design pressure for the system. Documentation of the potential for energy conservation when using a VFD is needed for center pivots equipped with various corner attachments.

The specific objective of this study was to develop robust estimates of the potential energy conservation by adjusting the pivot point pressure to account for the operation of corner attachments in 1000 fields with varying topography. In addition, the economic benefits of using a VFD to monitor and control pump impeller speed, such as annual savings and the payback period for the initial cost of the VFD, were determined for 1000 center-pivot sites.

\section{MATERIAL AND METHODS}

The study was conducted using center-pivot irrigated fields located in ten counties of Nebraska, as shown in figure 1. Counties were selected with a large population of center-pivot systems and a range of field topographies. The counties included in the study were Antelope, Box Butte, Butler, Cedar, Chase, Custer, Hamilton, Keith, Phelps, and Thayer. One hundred standard center-pivot systems were selected from each county (1000 total systems). The centerpivot systems (green dots in fig. 1) file was obtained from CALMIT for the year 2005 (https://calmit.unl.edu/2005-0), and $10 \mathrm{~m}$ elevation rasters were downloaded from USGSNED (USGS, n.d.).

Our previous work accounted for the impact of elevation change on the energy required for a standard center-pivot system (seven towers, no attachments) (Brar et al., 2017). For this work, two different corner attachments (end gun and corner extension) were used in three different scenarios:

Scenario 1: Standard center-pivot system equipped with an end gun.

Scenario 2: Standard center-pivot system equipped with a corner extension attached to the end of the last tower.

Scenario 3: Standard center-pivot system equipped with an end gun attached to the end of the corner extension described in scenario 2 .

These three scenarios were imposed on all 1000 centerpivot systems included in our data set. Assumptions for the 


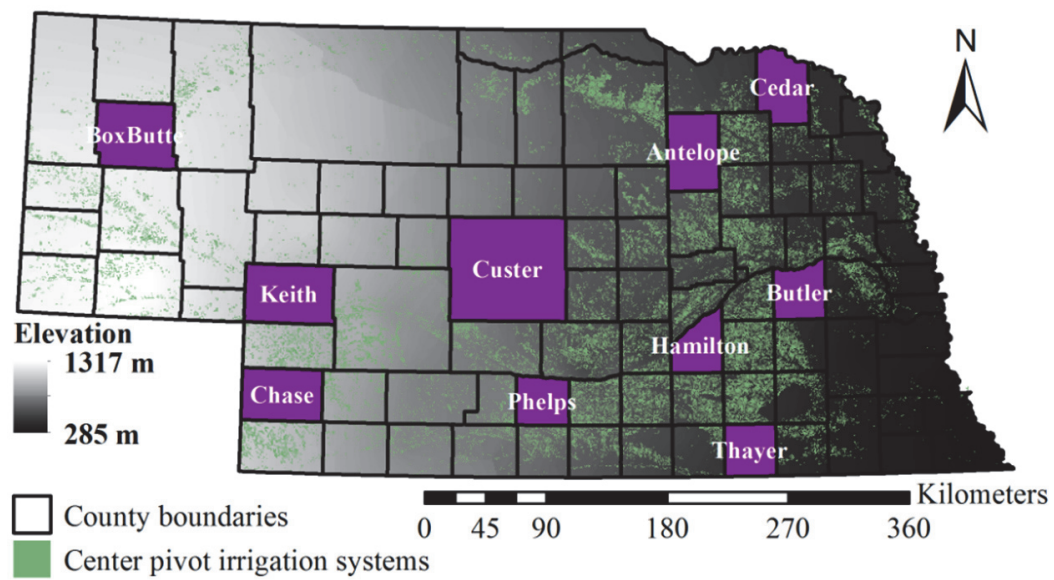

Figure 1. Locations of ten study counties, with center-pivot fields and elevation map of Nebraska in the background.

standard system were that the systems were $396 \mathrm{~m}$ long with seven equally spaced drive towers, as described by Brar et al. (2017), and additional assumptions for scenarios 1,2, and 3 are presented in tables 1,2 , and 3 , respectively. The pumping lifts used were the average pumping water levels for the wells in each county (NDNR, 2006). Although variable drawdowns may occur among the three scenarios due to differences in pump flow rate, the analysis considered a constant pumping lift. Due to variable aquifer characteristics, well development practices, date of installation, and the location of each irrigation well, a dependable pumping lift versus flow rate dataset was not available for all wells. It is likely that the use of a variable pumping lift would result in some differential outcomes for some installations. However, the magnitude of the overall differences would affect the averages only slightly.

\section{END GUN SELECTION}

The end guns used in this study were Nelson Big Gun 100 Series equipped with straight-bore nozzles, which were assumed to have an application rate curve very similar to the straight-bore nozzle Rainbird $105 \mathrm{C}$ end gun with angular operation of $135^{\circ}$, as described by Solomon and Kodoma (1978) (fig. 2). An agronomic $p$ factor of 0.5 was used considering the average aridity of the region in this study.

The end gun was selected according to the design criteria provided by Solomon and Kodoma (1978). The end gun was selected to distribute a particular application depth similar to that of the standard center pivot. However, end guns do not

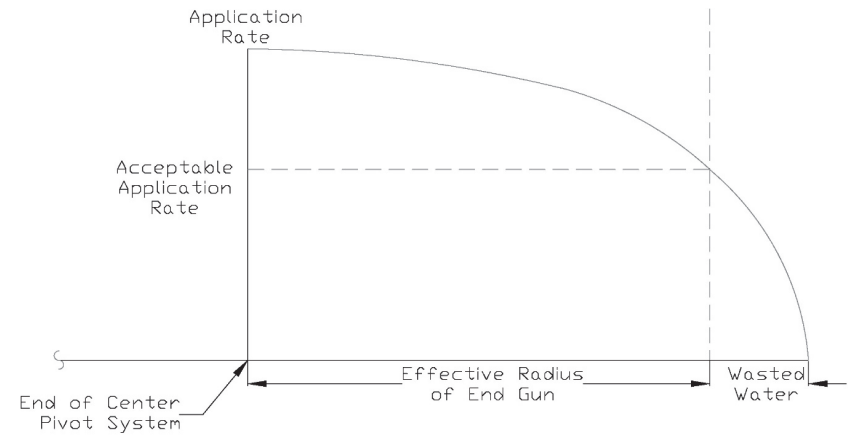

Figure 2. Demonstration of effective irrigated radius with acceptable application rate and the wasted water at the far end of the throw, which does not contribute to the acceptable crop growth. provide sufficient application depth at the outside edge of the application pattern, leaving some area with less than the full application. The irrigated area for the end gun was determined based on the effective radius of the end gun, as shown in figure 2. The effective end gun radius is the throw distance that provides a minimum application depth necessary to grow an acceptable crop. The effective radius, beyond which the application depth is unacceptable, does not depend on the end gun alone but is also dependent on the agronomic $p$ factor, which is determined according to the climatic and agronomic conditions. Solomon and Kodoma (1978) provided moving application rate curves for various sprinklers for determining the application rate curve parameter. This application rate curve parameter was used to determine the effective radius of the end gun, as shown in figure 2. Details regarding the application rate curves for different sprinklers and end guns are provided by Solomon and Kodoma (1978).

\section{CORNER EXTENSION SELECTION}

The corner extension chosen was $87.5 \mathrm{~m}$ in length, including $61 \mathrm{~m}$ of span length and $26.5 \mathrm{~m}$ overhang, with an inside pipe diameter of $160 \mathrm{~mm}$. The corner extension was attached to the last tower of a $396 \mathrm{~m}$ long standard center pivot. The flow rate increased linearly as the corner arm moved into the corner and was estimated using the Chu and Moe (1972) discharge distribution formula (eq. 1):

$$
Q_{r}=Q_{i n}\left(1-\frac{r^{2}}{R^{2}}\right)
$$

where

$$
\begin{aligned}
& Q_{r}=\text { flow rate at distance } \mathrm{r}\left(\mathrm{m}^{3} \mathrm{~s}^{-1}\right) \\
& Q_{i n}=\text { total system flow rate }\left(\mathrm{m}^{3} \mathrm{~s}^{-1}\right) \\
& r=\text { distance of flow rate calculation }(\mathrm{m}) \\
& R=\text { total length of the system }(\mathrm{m}) .
\end{aligned}
$$

\section{Procedure}

Geographical information system (GIS) tools included in ArcGIS 10.2 (ESRI, Redlands, Cal.) were used in this study, and the Nebraska center-pivot systems, state and boundary files used for the analysis were imported into the GIS environment as described by Brar et al. (2017). The procedure for all the three scenarios was an extension of that presented 
by Brar et al. (2017) except for the calculation of friction loss when the end gun and/or corner extension turns on. Similar to Brar et al. (2017), two approaches were used for all three scenarios:

Approach 1: Center pivot supplied with a constant design pressure at the pivot point by maintaining constant pump speed.

Approach 2: Center pivot supplied with the minimum required pressure at the pivot point for each degree of rotation by adjusting the pump speed using a VFD.

The operation of corner attachments shifts the operating point according to the shape of the pump performance curve when operating at a fixed speed (approach 1). This shifting of the operating point is pump-specific, as each pump impeller responds according to its performance curve. To simplify the selection, three pump impellers were selected and are presented in more detail below with the assumptions for each scenario. These pumps were selected to match the maximum flow rate and the pump outlet pressure required in each scenario. The greatest efficiency for all three pump models was standardized to $83 \%$ to make a good comparison of the decrease in efficiency with a decrease in flow rate. A relationship between the total dynamic head and the flow rate was developed for each selected pump impeller and was used for all 1000 center-pivot systems in that scenario. This was done by moving the pump performance curve vertically according to the required head in each field. The pump curve was shifted to the best efficiency point for the maximum head at the design flow rate. The relationship between the efficiency, head, and flow rate was developed to calculate the efficiency based on the total head required (due to varying speed) and the flow rate for each selected pump. An algorithm presented by Brar et al. (2017) was modified to add end gun and corner extension operation. Both of the approaches mentioned by Brar et al. (2017) were used to study the energy saved for the three scenarios described below.

\section{SCENARIO 1}

In scenario 1, an end gun was attached at the end of the overhang and actuated for $40^{\circ}$ in each of four quarters, increasing the irrigated area to 54 ha compared to 49 ha without an end gun. Figure 3 shows the movement of a centerpivot system in a 64.8 ha field with scenario 1 .

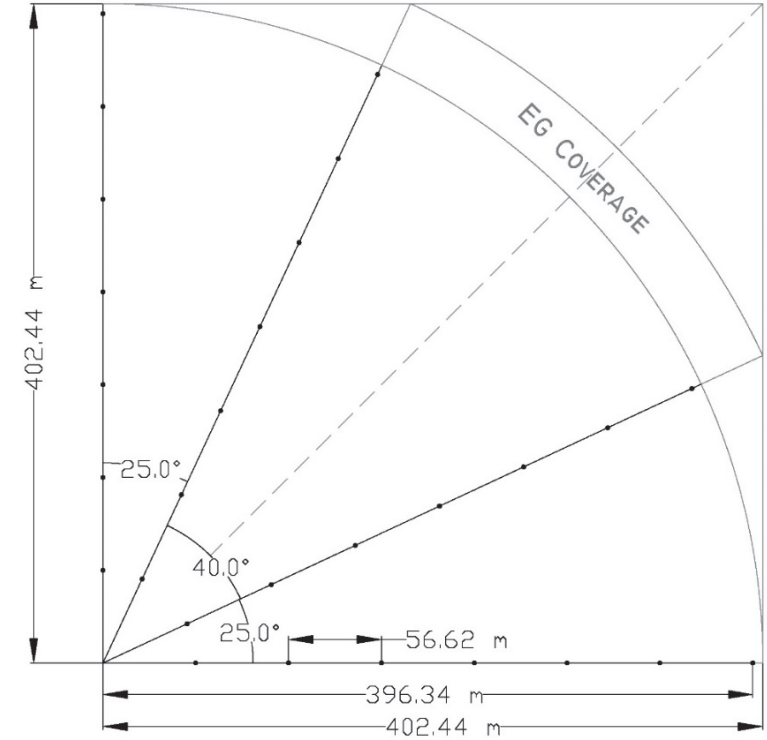

Figure 3. Quarter section of field showing movement of the center-pivot system in scenario 1. End gun coverage is the area irrigated by end gun actuation for $40^{\circ}$ at corner.

The pump impeller selected for this evaluation was a line shaft pump (model 12CMO, ITT Goulds Pumps, Seneca Falls, N.Y.) operating at a maximum efficiency of $83 \%$ at the maximum head requirement and maximum flow rate of $0.06 \mathrm{~m}^{3} \mathrm{~s}^{-1}$. A relationship was developed between the head and flow rate according to the shape of the pump performance curve and was used for all center-pivot systems in the study (fig. 4). The efficiency relationship indicated that the impeller efficiency varied from $83 \%$ at the greatest flow rate to $80 \%$ at minimum flow rate when the pump was operated at fixed speed of $1760 \mathrm{rpm}$ (approach 1). Approach 2 used the same relationship.

The end gun selection was made to deliver the same application depth provided by the standard center-pivot system. The Nelson Big Gun 100 Series with a $20.6 \mathrm{~mm}$ nozzle size was selected, with a design delivery rate of $0.009 \mathrm{~m}^{3} \mathrm{~s}^{-1}$ at $414 \mathrm{kPa}$ and a throw radius of $43 \mathrm{~m}$. The manufacturer's data were used to find the effective radius of the end gun, which was $37 \mathrm{~m}$. The angle for which end gun operated was also based on catalog radius to make sure that the end gun does not throw water out of the field boundaries.

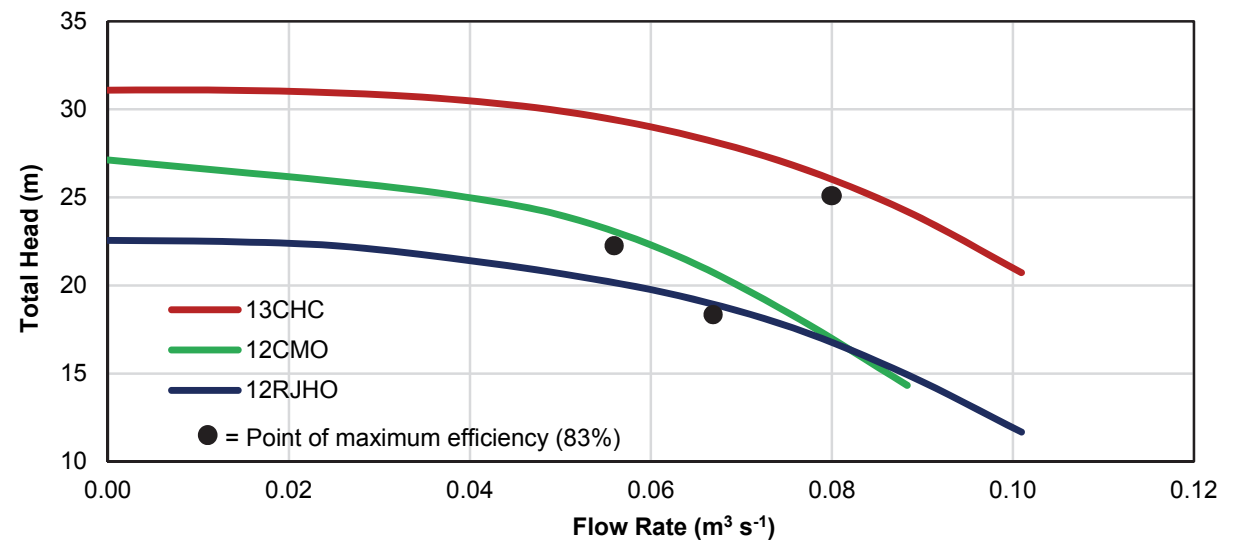

Figure 4. Gould's impeller performance curves for $1760 \mathrm{rpm}$ used in scenarios 1, 2, and 3 with the design point for each impeller (ITT Goulds Pumps, Seneca Falls, N.Y.). 
Specifications for a Nelson Big Gun 100 Series $(20.3 \mathrm{~mm}$ nozzle size) marketed by Nelson Irrigation (Walla Walla, Wash.) were used in equation 2 to develop the relationship between flow rate and pressure at the sprinkler. The relationship between pressure and flow rate was developed as shown in equation 3 :

$$
\begin{aligned}
& Q=C_{d} A \sqrt{2 g \Delta h} \\
& Q=0.000448 \sqrt{P}
\end{aligned}
$$

where

$Q=$ flow rate from sprinkler $\left(\mathrm{m}^{3} \mathrm{~s}^{-1}\right)$

$C_{d}=$ orifice discharge coefficient

$A=$ cross-sectional area of orifice $\left(\mathrm{m}^{2}\right)$

$g=$ gravitational acceleration $\left(\mathrm{m} \mathrm{s}^{-2}\right)$

$\Delta h=$ pressure head at base of sprinkler (m)

$P=$ pressure at end gun $(\mathrm{kPa})$.

The pressure used in equation 3 was calculated using a pressure of $207 \mathrm{kPa}$ before the end gun and the booster pump pressure of $207 \mathrm{kPa}$ to reach a total pressure at the end gun of $414 \mathrm{kPa}$. The flow rate from equation 3 was added to the system flow rate to calculate the total flow rate $\left(Q_{i n}\right)$, which will be used in equation 8 to calculate the end gun ratio.

Friction loss within the center-pivot lateral increased with flow rate to the end gun. Anwar (2000) extended the friction correction factor and pressure distribution factor developed by Chu and Moe (1972) to center pivots with end guns using a continuous outlet approach. This study further extended the model developed by Reddy and Apolayo (1988) for discrete outlets to calculate the friction correction factor and pressure distribution factors for center pivots with end guns. The study demonstrated that there were no significant differences between continuous and discrete outlet conditions for more than ten outlets. Scaloppi and Allen (1993b) proposed an equation to find the distribution of pressure head along a center-pivot lateral when an end gun sprinkler is in operation by using the effective irrigated radius (i.e., the length of the pivot plus the effective radius of the end gun sprinkler coverage). This approach was used by various researchers (Chu and Moe, 1972; Keller and Bliesner, 1990). Generally, the ratio of the lateral length to the effective irrigated radius was assumed to be less than or equal to 0.94 for typical centerpivot irrigated fields.

Later, Valiantzas and Dercas (2005) developed a new equation introducing a new term, the equivalent lateral length, that depends on the end gun ratio (i.e., the ratio of end gun discharge and total system discharge) instead of the effective irrigated radius. The equivalent lateral length is more suitable than the effective irrigated radius because it depends on the end gun ratio, eliminating the need to define the effective irrigated radius and any limiting ratio between lateral length and effective radius. Valiantzas and Dercas (2005) used the equivalent lateral length to calculate the total friction loss at any point of the lateral when the end gun is in operation for single-diameter and multi-diameter centerpivot laterals. The equation (eq. 4) provided by Valiantzas and Dercas (2005) was used to calculate the friction loss at each tower and a new pressure at the end gun, and the calculations were repeated to establish a new flow rate for the end gun. Equation 4 applied only for the $40^{\circ}$ of pivot rotation in which the end gun was in operation. The procedure developed for standard systems by Brar et al. (2017) applied to the remainder of the system rotation.

These calculations were iterated until the difference between the continuously calculated end gun flow rates was less than $0.00006 \mathrm{~m}^{3} \mathrm{~s}^{-1}\left(1 \mathrm{gal} \mathrm{min}^{-1}\right)$, which was assumed to be a negligible change. The final flow rate allowed computation of the friction loss at each system tower. Friction loss when the end gun was in operation was calculated using equation 4, developed by Valiantzas and Dercas (2005), for a single-diameter center-pivot lateral. The equivalent lateral length $\left(L_{e q}\right)$ is dependent on the end gun ratio $\left(g_{r}\right)$ which is based on the end gun discharge $\left(Q_{g}\right)$ at each angle as affected by the elevation at that particular angle:

$$
\begin{gathered}
h f_{(r)}= \\
S_{f 0} L_{e q}\left[\left(\frac{r}{L_{e q}}\right)-\frac{m}{3}\left(\frac{r}{L_{e q}}\right)^{3}+\frac{(m-1)}{(7-m)}\left(\frac{r}{L_{e q}}\right)^{7-m}\right] \\
S_{f 0}=K \frac{Q_{i n}^{m}}{D^{r_{o}}} \\
K=\frac{10.629}{C^{m}} \\
L_{e q}=\frac{R}{\sqrt{1-g_{r}}}
\end{gathered}
$$

End gun ratio was defined as:

$$
g_{r}=\frac{Q_{g}}{Q_{i n}}, 0 \leq g_{r} \leq 1
$$

where

$g_{r}=$ end gun ratio

$Q_{g}=$ discharge of end gun

$Q_{i n}=$ total inflow rate $\left(Q+Q_{g}\right)$

$L_{e q}=$ equivalent lateral length (m)

$K=$ friction coefficient based on Hazen-Williams friction formula

$S_{f 0}=$ friction loss slope of a similar fictitious pipe with single diameter $D$ transmitting the entire flow $Q_{i n}$ over its length

$m=$ velocity exponent $(1.852)$

$r_{o}=$ diameter exponent (4.87).

The $1.84 \mathrm{~kW}$ end gun booster pump operated in all the four corners of the field ( $40^{\circ}$ at each corner). A summary of the assumptions made in scenario 1 is shown in table 1 . The steps performed to determine pivot point pressure, water horsepower, and brake horsepower were described in detail by Brar et al. (2017). Pivot point pressure was calculated at each degree of rotation for approaches 1 and 2 . The difference in pressure between the approaches represents the pressure reduction resulting from use of a VFD and allowed calculation of the energy savings for each degree of rotation. 
Table 1. Assumptions in scenario 1.
Area irrigated

Pump model

Diameter of pump impeller Design flow rate

Nozzle diameter of end gun

End gun operation in each corner

Catalog radius at $414 \mathrm{kPa}$

Effective radius at $414 \mathrm{kPa}$
54 ha

Goulds 12CMO

$220 \mathrm{~mm}$

$0.06 \mathrm{~m}^{3} \mathrm{~s}^{-1}$

$40^{\circ}$

$43 \mathrm{~m}$

$37 \mathrm{~m}$
$20.6 \mathrm{~mm}$

\section{SCENARIO 2}

In scenario 2, a corner extension was attached to the last tower of the standard center-pivot system. As the pivot rotated, the corner extension traveled through three zones: extension zone from $0^{\circ}$ to $35^{\circ}$, fully extended zone from $36^{\circ}$ to $55^{\circ}$, and retraction zone from $56^{\circ}$ to $90^{\circ}$ (fig. 5). Use of the corner extension increased the area irrigated by 6 ha when compared to scenario 1 , and the total irrigated acres increased to 60 ha.

The maximum flow rate in this scenario increased to $0.07 \mathrm{~m}^{3} \mathrm{~s}^{-1}$ when the corner extension was fully extended. The line shaft pump impeller (model 12RJHO, ITT Goulds Pumps, Seneca Falls, N.Y.) was selected to match the flow rate and design head requirement. Again, the relationship between the pumping head and flow rate of this pump impeller was based on the shape of the pump performance curve (fig. 4) to show the increase in pressure as the flow rate decreased in approach 1 . The efficiency relationship with head and flow rate was developed to calculate the efficiency for varying head and flow rate in approaches 1 and 2 .

The flow rate increased linearly as the corner extension traveled from $0^{\circ}$ in the extension zone to a maximum in the fully extended zone, remained almost constant in the fully extended zone, and then decreased linearly from the fully extended zone to $90^{\circ}$ in the retraction zone. The flow rate was calculated using equation 1 ; it increased from 0 to $0.024 \mathrm{~m}^{3} \mathrm{~s}^{-1}$ as the corner extension moved from $0^{\circ}$ to fully extended in the extension zone and decreased to $0 \mathrm{~m}^{3} \mathrm{~s}^{-1}$ at the $90^{\circ}$ retraction point. Friction loss in this scenario was

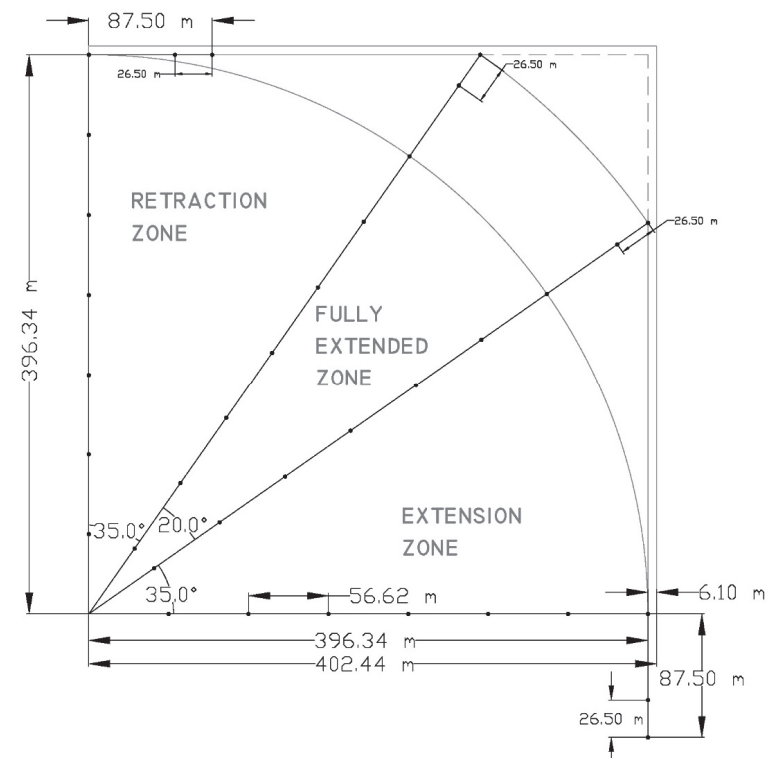

Figure 5. A 65 ha field showing movement of the center-pivot system in scenario 2. Movement of the $87.5 \mathrm{~m}$ corner extension is shown as the system passes through one $90^{\circ}$ corner of the field. calculated using both the Valiantzas and Dercas (2005) equation (eq. 4) and the Chu and Moe (1972) equation (eq. 11).

Equation 4 was used to calculate friction loss in the main center-pivot system assuming the corner extension flow rate as the end gun flow rate. For friction loss due to the extension, equation 11 was used, assuming a hypothetical centerpivot system that had uniform flow. The flow rate used in equation 10 to calculate $h f_{(R)}$ was calculated using equation 1 . Friction loss using equation 11 was calculated at three lengths: (1) center-pivot length without a corner extension $(r=396 \mathrm{~m})$, (2) at the eighth tower $(r=457 \mathrm{~m})$, and (3) at the end of the overhang $(r=484 \mathrm{~m})$. Friction loss in the span of the corner extension and in the overhang was calculated separately using equations 13 and 14, respectively:

$$
\begin{gathered}
\text { H-W eq. }=H f_{(R)}=10.67 \times\left(\frac{1}{C}\right)^{1.852} \times \frac{Q^{1.852}}{D^{4.87}} \times R \\
h f_{(R)}=0.548 \times 10.67 \times\left(\frac{1}{C}\right)^{1.852} \times \frac{Q^{1.852}}{D^{4.87}} \times R \\
h f_{(r)}=h f_{(R)} \times \frac{15}{8}\left(x-\frac{2 x^{3}}{3}+\frac{x^{5}}{5}\right) \\
x=\frac{r}{R}
\end{gathered}
$$

where

$C=\mathrm{H}-\mathrm{W}$ pipe roughness coefficient

$Q=$ system flow rate $\left(\mathrm{m}^{3} \mathrm{~s}^{-1}\right)$

$D=$ pipe inside diameter $(\mathrm{m})$

$R=$ total length of pivot lateral (m)

$r=$ distance of friction loss calculation $(\mathrm{m})$

$h f_{(R)}=$ friction loss at distance $R(\mathrm{~m})$

$h f_{(r)}=$ friction loss at distance $r(\mathrm{~m})$.

$$
\begin{gathered}
H f_{\text {span }}=h f_{(457)}-h f_{(396)} \\
H f_{\text {overhang }}=h f_{(484)}-h f_{(457)}
\end{gathered}
$$

where

$H f_{\text {span }}=$ friction loss in span of corner extension (m)

$H f_{\text {overhang }}=$ friction loss in overhang of extension $(\mathrm{m})$

$h f_{(457)}=$ friction loss in system to eighth tower $(\mathrm{m})$

$h f_{(396)}=$ friction loss in system to seventh tower $(\mathrm{m})$

$h f_{(484)}=$ friction loss in system in the overhang $(\mathrm{m})$.

The friction loss calculated using equations 13 and 14 was added to the original friction loss calculated for the standard center-pivot system using equation 4 to find the total friction loss. Solenoid valves are often used before the sprinklers in the corner extension to control the flow rate. The friction loss in the solenoid-operated hydraulic valves was accounted for within the pressure regulator loss of $34 \mathrm{kPa}$ assumed in this study, as it generally ranged from 13 to $16 \mathrm{kPa}$.

All the assumptions made in scenario 2 are shown in table 2. The pivot point pressure, water horsepower, brake horsepower, and energy or monetary savings were quantified as described by Brar et al. (2017). 
Table 2. Assumptions in scenario 2.

Area irrigated

Pump impeller

Diameter of pump impeller

Design flow rate

Length of corner extension

Flow rate range in corner extension

\section{SCENARIO 3}

Scenario 3 was a combination of scenarios 1 and 2 . The corner extension in scenario 2 was equipped with an end gun, which was selected by using the same procedure explained in scenario 1. The straight-nozzle Nelson Big Gun 100 Series delivering $0.011 \mathrm{~m}^{3} \mathrm{~s}^{-1}$ at $414 \mathrm{kPa}$ with a throw radius of $45 \mathrm{~m}$ with a $22.9 \mathrm{~mm}$ nozzle size was selected. This nozzle size was sufficient to satisfy the effective radius of $38 \mathrm{~m}$ found using the catalog radius. The specifications of the Nelson Big Gun 100 Series (22.9 mm nozzle size) provided by Nelson Irrigation (Walla Walla, Wash.) were used in the orifice equation (eq. 15) to develop the relationship between flow rate and pressure at the end gun:

$$
Q=0.000577 \sqrt{P}
$$

In this scenario, when the corner extension was fully extended, the end gun was activated, and the flow rate supplied to the corner extension increased to $0.085 \mathrm{~m}^{3} \mathrm{~s}^{-1}$. A Goulds pump (model 13CHC, ITT Goulds Pumps, Seneca Falls, N.Y.) was selected to operate at $83 \%$ efficiency at the maximum required head and maximum required flow rate $\left(0.085 \mathrm{~m}^{3} \mathrm{~s}^{-1}\right)$. The relationship between head and flow rate for the model $13 \mathrm{CHC}$ impeller is shown in figure 4 for a fixed impeller speed installation. This relationship was used to evaluate the energy conservation for 1000 center-pivot systems operating under Nebraska conditions.

The total irrigated area for this scenario increased to $61.5 \mathrm{ha}$, an increase of 1.5 or 0.4 ha per corner. The corner extension functioned in the same manner as described for scenario 2 except that the end gun turned on for $9^{\circ}$ at each corner (first quarter $=41^{\circ}$ to $49^{\circ}$, second quarter $=131^{\circ}$ to $139^{\circ}$, third quarter $=221^{\circ}$ to $229^{\circ}$, and fourth quarter $=311^{\circ}$ to $319^{\circ}$ ). A schematic of scenario 3 is presented in figure 6 . For the time when the end gun was in operation, equation 4, presented by Valiantzas and Dercas (2005), was used to calculate the friction loss at each tower (including the corner extension) and at the overhang, assuming that the main center pivot and the corner extension formed a single system for $9^{\circ}$. The friction loss for other angular positions was calculated in a manner similar to scenario 2 .

All the assumptions made in scenario 3 are shown in table 3. An example of the distribution of center-pivot point pressure using approach 1 (fixed motor speed) and approach 2 (varying motor speed using VFD) for all three scenarios is presented in figure 7 .

\section{RESULTS AND DISCUSSION Mean Design Pressure}

The pump was selected to supply the required head at the maximum required flow rate at the best efficiency point when the pump was operated at fixed speed (approach 1). If the flow

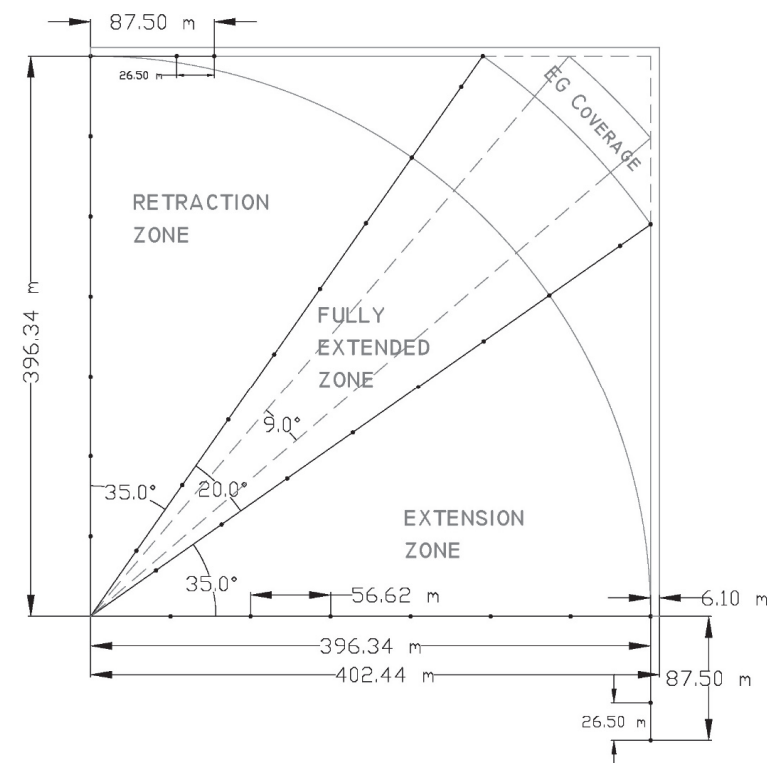

Figure 6. A 65 ha field showing movement of the center-pivot system in scenario 3. The corner extension and end gun coverage areas are shown with the on/off angular positions.

Table 3. Assumptions in scenario 3.

Area irrigated Pump type selected Diameter of pump impeller Design flow rate Nozzle diameter of end gun

End gun actuation angle in each corner Catalog radius at $414 \mathrm{kPa}$ Effective radius at $414 \mathrm{kPa}$

$61.5 \mathrm{ha}$
Goulds $13 \mathrm{CHC}$
$233 \mathrm{~mm}^{3}$
$0.085 \mathrm{~m}^{3} \mathrm{~s}^{-1}$
$22.9 \mathrm{~mm}$
$9^{\circ}$
$45 \mathrm{~m}$
$38 \mathrm{~m}$

decreases when some sprinklers are shut off, the operating head increases according to the pump curve, which results in decreased impeller efficiency. The magnitude of the increase in operating head is totally dependent on the pump impeller design and thus is different for each impeller model.

The maximum design pressure required for center pivots averaged over each study county for scenarios 1, 2, and 3 was calculated using approach 1 as discussed by Brar et al. (2017). As expected, the design pressure increased from scenario 1 to scenario 3 in all ten counties (table 4 ). The primary reason for the increase in design pressures with each scenario was the greater pipeline friction losses incurred due to the increased flow rates. To a lesser degree and for scenarios 2 and 3, elevation change impacted design pressure when the elevation was greater at the corner extension tower.

Overall, the increase in mean design pressure was approximately $30 \mathrm{kPa}$ when an end gun was attached to the end of the center-pivot lateral (scenario 1) when compared to a standard center-pivot system. On average, the pressure increased by an additional $85 \mathrm{kPa}$ with the attachment of a corner extension (scenario 2, table 4). The greatest increase for an individual county was recorded in Custer County, where the average increase was $96 \mathrm{kPa}$. When an integrated corner extension and end gun (scenario 3 ) were added, the average pivot point pressure increased by an additional $72 \mathrm{kPa}$.

In scenario 1 , the maximum required pivot pressure was calculated for Cedar County (465 kPa), followed closely by Custer County $(462 \mathrm{kPa})$. Butler and Hamilton Counties produced the least required pivot pressure. However, in scenar- 

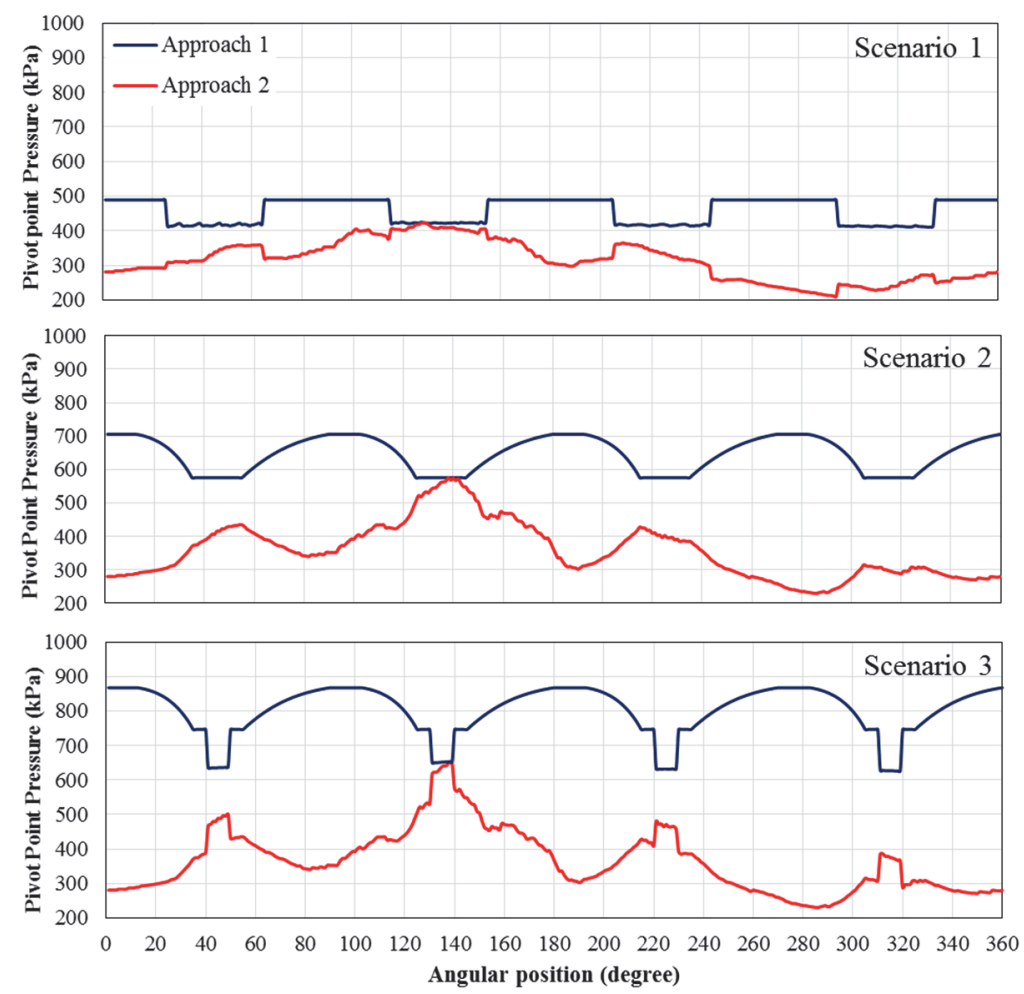

Figure 7. Center pivot point pressure distribution for each degree of rotation using approaches 1 and 2 for scenarios 1,2 , and 3.

Table 4. Mean design pressure (kPa) using approach 1 for scenarios 1 , 2 , and 3 in study counties.

\begin{tabular}{cccc}
\hline & \multicolumn{3}{c}{ Mean Pivot Point Pressure (kPa) } \\
\cline { 2 - 4 } County & $\begin{array}{c}\text { Scenario 1 } \\
\text { (End gun) }\end{array}$ & $\begin{array}{c}\text { Scenario 2 } \\
\text { (Corner } \\
\text { extension) }\end{array}$ & $\begin{array}{c}\text { Scenario 3 } \\
\text { (Corner extension } \\
\text { and end gun) }\end{array}$ \\
\hline Antelope & 425 & 512 & 581 \\
Box Butte & 393 & 476 & 549 \\
Butler & 379 & 464 & 538 \\
Cedar & 465 & 552 & 616 \\
Chase & 383 & 469 & 543 \\
Custer & 462 & 558 & 620 \\
Hamilton & 378 & 460 & 535 \\
Keith & 395 & 481 & 554 \\
Phelps & 381 & 465 & 538 \\
Thayer & 385 & 467 & 541 \\
Mean & 405 & 490 & 562 \\
\hline
\end{tabular}

ios 2 and 3, this order shifted, with the maximum pressure being observed in Custer County, followed by Cedar County (table 4). The magnitude of elevation differences in both counties was similar, so the explanation of this outcome is that the elevation at the location of the corner extension was greater in Custer County than in Cedar County. The same outcome was reported for Thayer and Chase Counties, with Chase County displaying greater pressure than Thayer County under scenarios 2 and 3 . The minimum mean design pressure was observed in Hamilton County in all three scenarios (table 4). On average, the addition of a corner extension and end gun increased the pressure requirement by $157 \mathrm{kPa}$, or a $42 \%$ increase over a standard system without an end gun (Brar et al., 2017).

\section{ACtual Required Pressure}

The minimum pressures required using approach 2 for all three scenarios and each degree of rotation were calculated for the 1000 center-pivot fields in ten counties. The mean pressure reduction for approach 2 compared to approach 1 was calculated for the 100 center-pivot sites in each county. The pressure reductions encountered in the all three scenarios were greater than the reduction for a standard centerpivot system without a corner attachment, discussed by Brar et al. (2017). The pressure reductions were due to difference in pivot point pressure among both approaches. The design pressure increased with each progressive addition of flow rate, whereas the pivot point pressure in approach 2 increased at those segments of the pivot rotation where corner attachments came into use, with the operating pressure remaining the same for the rest of the angular positions, which is evident in figure 7. In addition, in approach 1 , in which the pump speed was fixed, the operating pressure was even greater than the design pressure when the flow rate decreased, according to the pump performance curve. In approach 2 , the minimum required pressure was achieved by decreasing the speed of the pump.

The greatest reductions were recorded for scenario 3, followed by scenario 2 and scenario 1 . Reductions in required pressure for pivots in the ten study counties for each scenario are presented in figure 8 . The maximum pressure reduction was 440,522 , and $554 \mathrm{kPa}$ in Custer County for scenarios 1 , 2 , and 3 , respectively. Overall, the maximum pressure reduction for the ten counties averaged 284,393 , and $460 \mathrm{kPa}$ for scenarios 1,2 , and 3 , respectively (fig. 8). This information shows that the pressure varied greatly within the field and county.

The ability to monitor and control pressure by VFDs can provide adequate pivot point pressure, despite changes in field elevation and flow rate, which can conserve energy when compared to a constant-speed pump installation. 

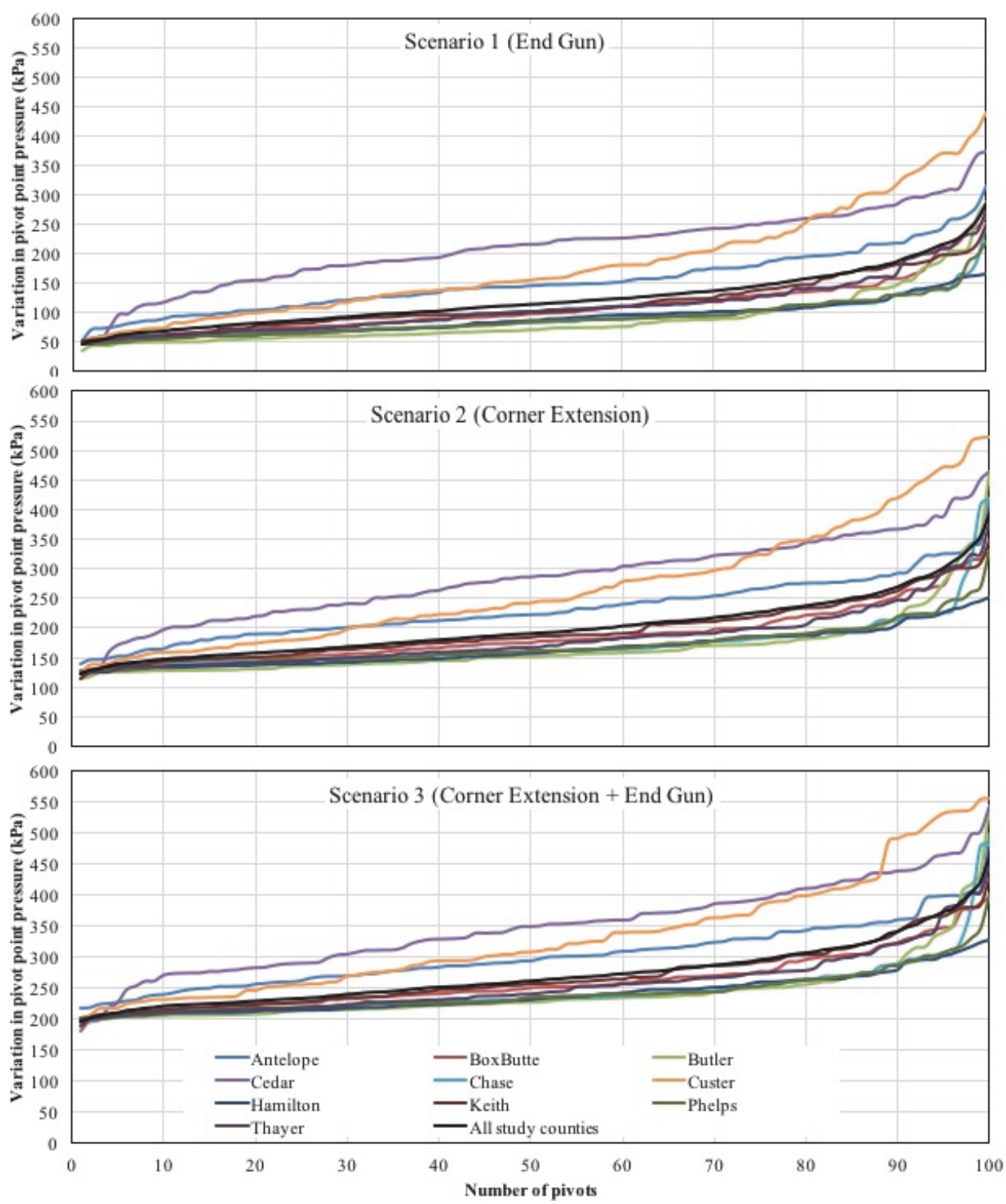

Figure 8. Pivot point pressure variation in each center-pivot system in scenarios 1, 2, and 3 for the ten study counties.

\section{ENERGY USE REDUCTION}

Minimizing the pressure supplied to each center-pivot system (approach 2) often leads to energy use reduction in the form of electricity $(\mathrm{kWh})$ because the pressure requirements can be fulfilled with less energy. Energy reduction as a function of the number of center pivots in each county for all three scenarios is presented in figure 9. In scenario 1, use of VFDs on all pivots in each county reduced the energy requirements by at least $4 \%$. The maximum energy saved by any pivot in the study was in Custer County, with an energy reduction of $29 \%$. About $80 \%$ of the center pivots in Cedar County reduced energy needs by more than $12 \%$, whereas this reduction was achieved by $45 \%$ of the center pivots in Custer County and by $42 \%$ in Antelope County. However, less than $20 \%$ of the pivots in other counties were able to show similar energy reductions. When all 1000 pivots were included, $23 \%$ were able to achieve $12 \%$ reduction. The maximum reduction in Hamilton County by any pivot was just $13 \%$ in scenario 1.

In scenario 2 , every pivot in every county used less en- ergy or reduced the energy consumption by at least $11 \%$. The maximum reduction by any pivot among all the counties was in Chase County (35\%), closely followed by Custer County $(34 \%)$. In this scenario, more than $80 \%$ of the pivots in Cedar County and about $60 \%$ in Antelope and Custer Counties were able to achieve energy reductions greater than $18 \%$, whereas less than $25 \%$ of the pivots were able to show that level of energy use reduction in the remaining counties. Just $34 \%$ of the 1000 total pivots reduced energy usage by $18 \%$, as shown in figure 9 .

In scenario 3, energy use for approach 1 was reduced by a minimum of $23 \%$ for the 1000 pivots in ten counties when compared with approach 2 . When compared to a constantspeed pump (approach 1), the maximum energy use reduction by any pivot using a VFD (approach 2) was $41 \%$, as recorded in Cedar and Chase Counties. Scenario 3 showed consistent energy reductions, with $70 \%$ of the pivots reducing energy requirements more than $28 \%$ compared to approach 1 . About $45 \%$ of the pivots in all ten counties reduced energy use more than $28 \%$ using a VFD. 


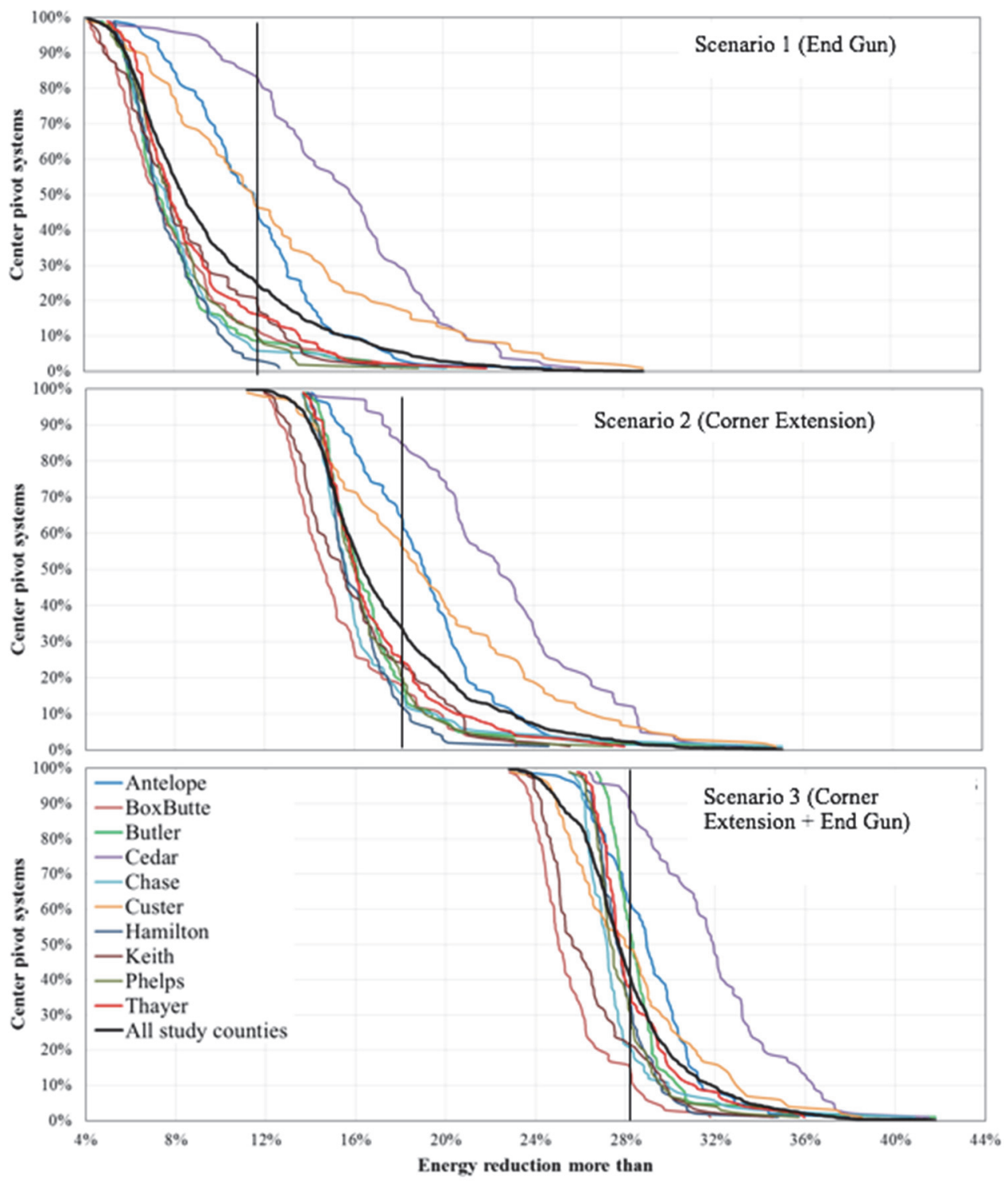

Figure 9. For each study county, the exceedance function of energy use reduction using approach 2 in scenarios 1,2 , and 3 where a VFD was employed to supply the exact pressure required to meet the pressure required by all sprinklers on the center pivot.

With the progression of scenarios, the range of energy reductions within counties became narrower (fig. 9). The reason for this was the major dependence of energy reduction on the pump performance curve instead of the elevation difference, as presented by Brar et al. (2017).

As additional corner watering attachments were added, the flow rate increased considerably due to the area irrigated by the center pivot. The pump is designed for the greatest flow rate; however, when the center pivot exits each corner of the field, the flow rate decreases, and the operating point on the pump curve is shifted to the left and to a lower impeller efficiency. The level of energy use reduction experienced through use of a VFD to control the pump speed is impacted by the proportion of the area irrigated when the system is fully extended. Because scenario 3 includes a pump design based on $9^{\circ}$ of operation in each of the four corners, or $36^{\circ}$ and just $10 \%$ of a revolution, scenario 3 will always result in the greatest potential energy use reduction when compared to scenarios 1 and 2.
The shape of the pump curve determines how significant the energy use reduction is for each installation. A pump curve that is designed for a specific set of operating conditions generally has a specific slope (head vs. flow rate), which results in a specific head output per decrease in flow rate. If the pump is selected for a situation in which the pumping water level fluctuates and/or the system supplies water to more than one installation, the pump curve could have a relatively flat slope (head vs. flow rate), which results in less increase in head per decrease in flow rate. The steeper the performance curve, the greater the energy consumption is at a fixed pump speed (approach 1), but greater energy reductions result from adjusting the pump speed (approach 2).

The average energy reduction using approach 2 in all ten counties for scenarios 1,2 , and 3 is presented in figure 10 . Cedar County had the greatest average energy use reductions of $16 \%$ in scenario $1,23 \%$ in scenario 2 , and $32 \%$ in scenario 3 , followed by Custer County in all three scenarios 


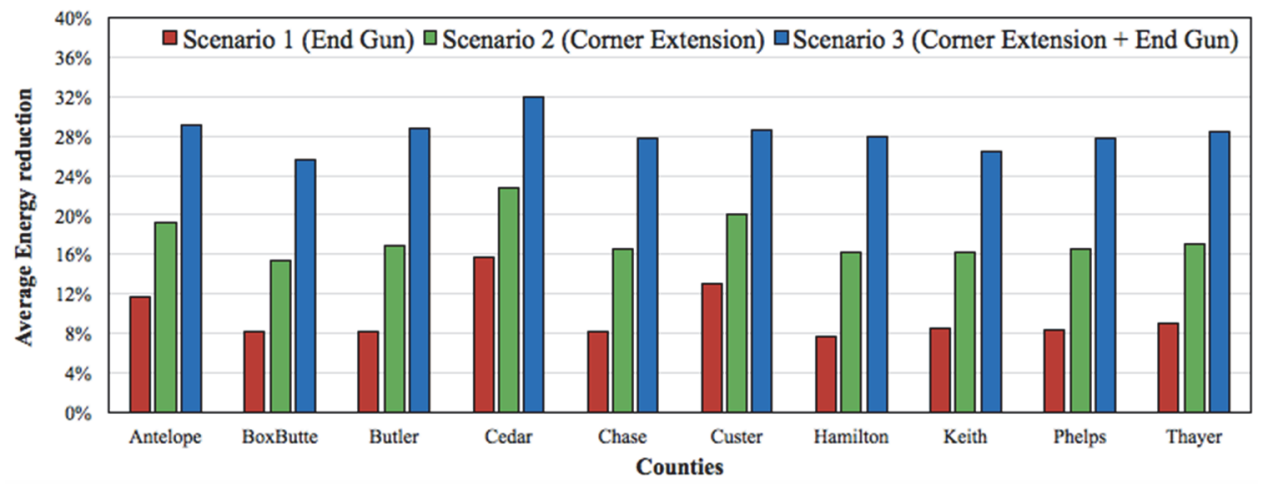

Figure 10. Average percentage of energy use reduction by using approach 2 relative to approach 1 in scenarios 1,2 , and 3.

(fig. 10). Box Butte County had the least average energy use reductions of $8 \%$ in scenario $1,15 \%$ in scenario 2 , and $26 \%$ in scenario 3. The reduction in energy use increased by nearly $7 \%$ in almost every county by adding an end gun to the standard system (scenario 1 ). The increase rose to $13 \%$ in most of the counties when a corner extension was added (scenario 2). By attaching an end gun at the end of the corner extension (scenario 3 ), the increase was $26 \%$. The average county energy use reduction in approach 2 (with VFD) was at least $8 \%, 15 \%$, and $26 \%$ in scenarios 1,2 , and 3, respectively.

The relationship between energy use reduction and field elevation difference for a full rotation in every pivot (360,000 points) using approach 2 and the elevation difference with respect to the design elevation in the field was developed and is shown in figure 11. Unlike the strong rela- tionship observed when the center pivot is equipped with no corner equipment (Brar et al., 2017), the relationship in all three scenarios was not that strong. The coefficient of determination $\left(\mathrm{r}^{2}\right)$ decreased as additional corner watering attachments were added to the center pivot in scenarios 1 to 3 . The major cause was the increase and decrease in flow rate that results due to switching the corner attachments on and off. Moving from scenario 1 to scenario 3, the range of flow rates widens, indicating the dependence of energy reduction on other factors, such as the shape of the pump performance curve, rather than the elevation difference.

\section{ELECTRICAL ENERGY SAVED}

As discussed earlier, the irrigated area of the fields differed according to the three scenarios, i.e., 54 ha for scenario 1,60 ha for scenario 2 , and 61.5 ha for scenario 3 . Using net
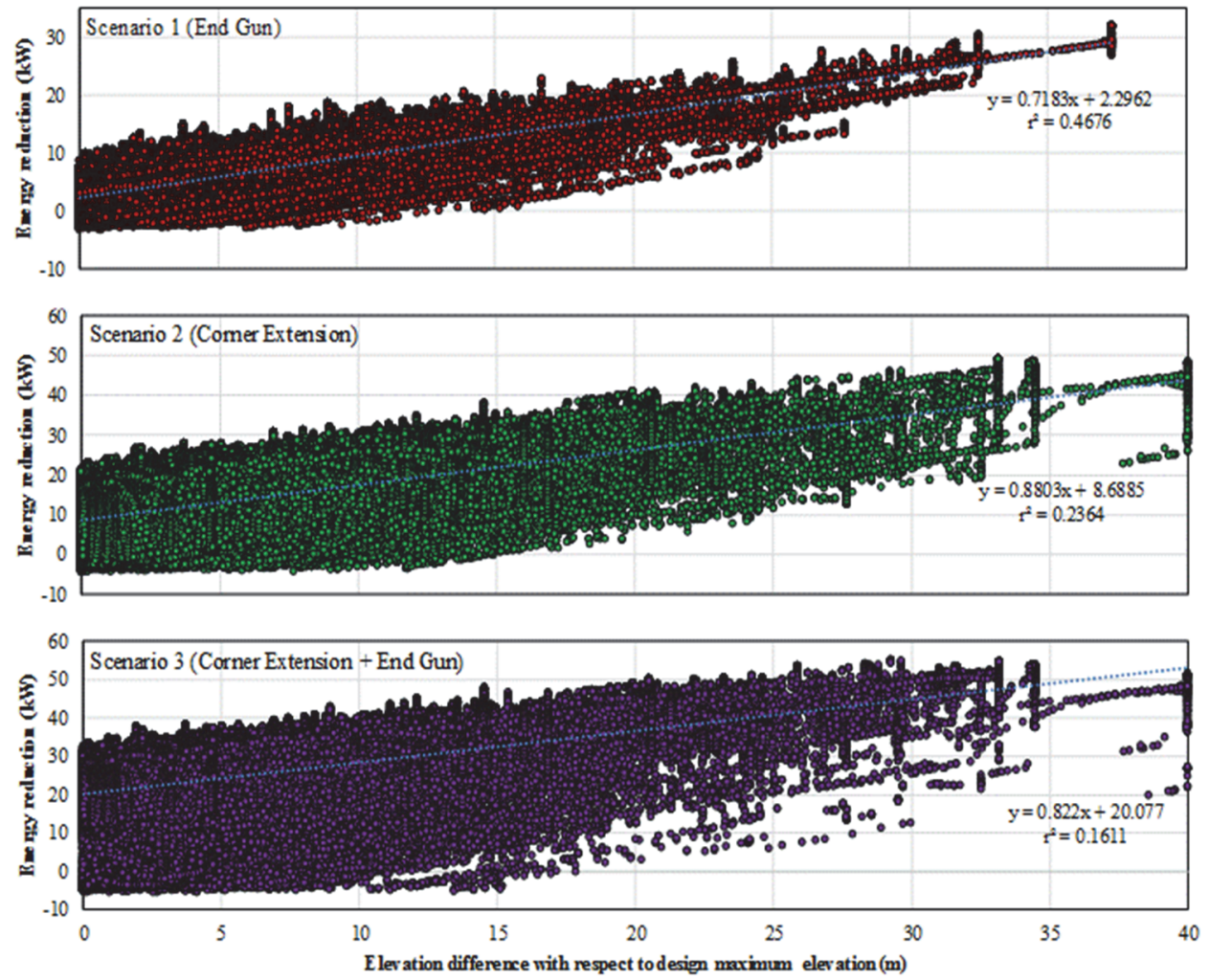

Figure 11. Relationship between energy use reduction and field elevation differences (elevation difference between the design elevation of the pivot and the maximum tower elevation at that degree of the pivot) and the potential energy conservation for 1000 center pivots selected at random from ten counties in scenarios 1,2 , and 3. 
irrigation requirements for the state of Nebraska (NDNR, 2006), a fixed level of center-pivot water application efficiency of $85 \%$, and the average flow rate in each scenario, irrigated hours were calculated as described by Brar et al. (2017). The average electrical energy (kWh) saved in each county for each scenario was calculated using county-specific irrigated hours (ranging from 500 to $1000 \mathrm{~h}$ ) per year, as shown in figure 12 . The greatest annual electrical energy saved per center pivot was 9346 and $18,663 \mathrm{kWh}$ in scenarios 1 and 2, respectively, in Custer County and 33,512 kWh in scenario 3 in Box Butte County. In scenario 1, the energy savings ranged from $2968 \mathrm{kWh}$ (Butler County) to $9346 \mathrm{kWh}$ (Custer County). In scenario 2, the energy savings ranged from $8176 \mathrm{kWh}$ (Butler County) to $18,663 \mathrm{kWh}$ (Custer County). In scenario 3, the energy savings varied from 16,835 kWh (Butler County) to 33,512 kWh (Box Butte County). The range in values is strongly tied to the net irrigation requirement, which was greater in Box Butte County.

\section{MONETARY SAVINGS IN RELATION TO OPERABLE HOURS}

The annual energy cost savings for each scenario was converted to potential monetary savings per center pivot and per hectare using the net irrigation requirement (values obtained from Nebraska Department of Natural Resources; table 5, column 2), irrigation hours (table 5, columns 3 to 5), and financial savings per hour (table 5, columns 6 to 8 ) for each county and are presented in table 6 .

In scenario 1, the greatest financial savings when using a VFD were observed in Custer County (\$1042), followed by
Cedar County (\$862). The least savings were \$331 and \$370 observed in Butler and Hamilton Counties, respectively. In scenario 2, Antelope, Box Butte, Cedar, Chase, Custer, Keith, and Phelps Counties showed savings greater than $\$ 1300$ in the growing season. In scenario 3, every county saved more than $\$ 1800$ annually. Box Butte, Chase, Custer, and Keith Counties produced nearly $\$ 3000$ in savings annually, with a maximum of $\$ 3737$ by Box Butte County. The least savings in scenario 3 was recorded in Butler County (\$1877). The average savings per hectare of area were also calculated for each county in each scenario (table 6).

\section{CAPITAL INVESTMENT IN VFDS}

The most important question is whether or not VFD installation is economical. The answer depends on the annual savings (dollars) from a specific center-pivot system. The average annual savings for each county was used to calculate the investment dollars available for a VFD installation in a particular county. A series present worth factor of 9.11 was used based on repayment of a loan at $7 \%$ annual interest and a loan repayment period equal to the estimated economic life of a VFD (15 years). The calculated results are presented in table 7.

The power rating of VFDs that would be appropriate considering the design brake horsepower was found to be 45 , 60 , and $75 \mathrm{~kW}$ for scenarios 1,2 , and 3, respectively. The initial VFD cost estimates of $\$ 12,000, \$ 16,000$, and $\$ 20,000$ (capital cost only) for scenarios 1,2 , and 3, respectively, were based on an average cost of $\$ 267$ per $\mathrm{kW}$. On average, the calculated annual savings for scenario 1 were insufficient to repay a loan at $7 \%$ interest in 15 years (table 7 ).

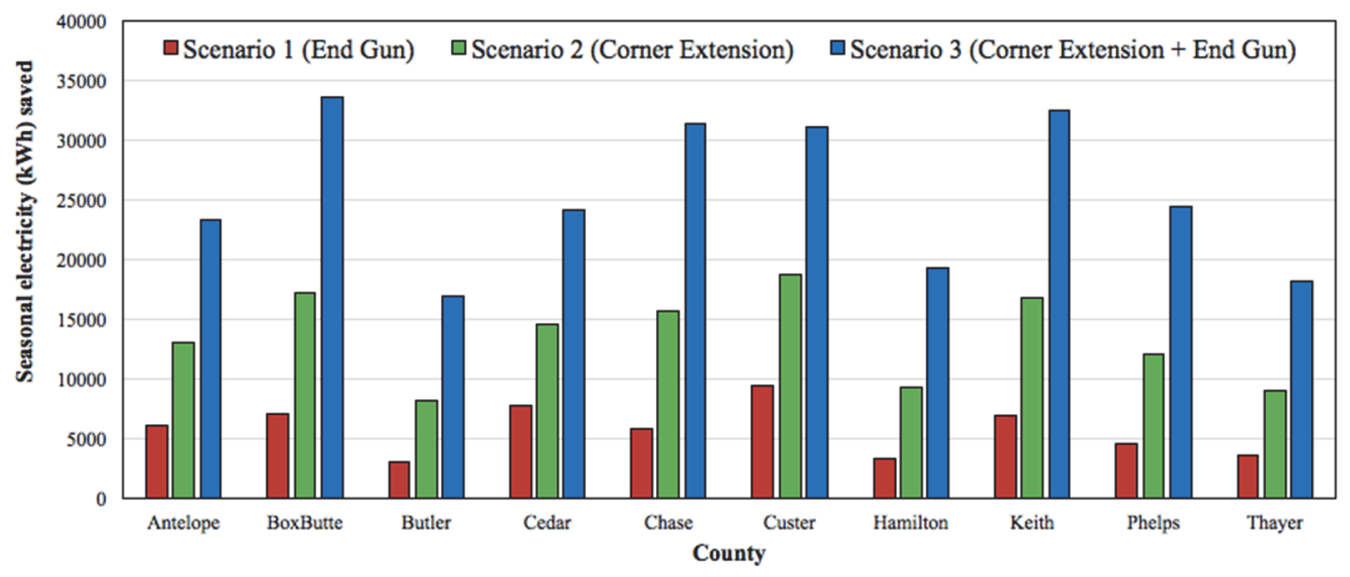

Figure 12. Seasonal average electrical energy $(\mathrm{kWh})$ saved in scenarios 1, 2, and 3 in each county.

Table 5. Number of irrigation hours and savings per hour in each county in scenarios 1,2 , and 3.

\begin{tabular}{|c|c|c|c|c|c|c|c|}
\hline \multirow[b]{2}{*}{ County } & \multirow{2}{*}{$\begin{array}{c}\text { Net } \\
\text { Irrigation } \\
\text { Requirement } \\
(\mathrm{mm})\end{array}$} & \multicolumn{3}{|c|}{ Annual Irrigation Hours (h) } & \multicolumn{3}{|c|}{ Hourly Savings (USD) } \\
\hline & & $\begin{array}{l}\text { Scenario } 1 \\
\text { (End gun) }\end{array}$ & $\begin{array}{l}\text { Scenario 2 } \\
\text { (Corner } \\
\text { extension) }\end{array}$ & $\begin{array}{c}\text { Scenario } 3 \\
\text { (Corner extension } \\
\text { and end gun) }\end{array}$ & $\begin{array}{l}\text { Scenario } 1 \\
\text { (End gun) }\end{array}$ & $\begin{array}{l}\text { Scenario 2 } \\
\text { (Corner } \\
\text { extension) }\end{array}$ & $\begin{array}{c}\text { Scenario } 3 \\
\text { (Corner extension } \\
\text { and end gun) }\end{array}$ \\
\hline Antelope & 226 & 622 & 609 & 610 & 1.1 & 2.4 & 4.3 \\
\hline Box Butte & 356 & 978 & 958 & 959 & 0.8 & 2.0 & 3.9 \\
\hline Butler & 185 & 510 & 499 & 500 & 0.6 & 1.8 & 3.8 \\
\hline Cedar & 216 & 594 & 581 & 582 & 1.5 & 2.8 & 4.6 \\
\hline Chase & 338 & 929 & 910 & 911 & 0.7 & 1.9 & 3.8 \\
\hline Custer & 284 & 782 & 766 & 767 & 1.3 & 2.7 & 4.5 \\
\hline Hamilton & 213 & 587 & 575 & 575 & 0.6 & 1.8 & 3.7 \\
\hline Keith & 338 & 929 & 910 & 911 & 0.8 & 2.1 & 4.0 \\
\hline Phelps & 267 & 734 & 718 & 719 & 0.7 & 1.9 & 3.8 \\
\hline Thayer & 196 & 538 & 527 & 527 & 0.7 & 1.9 & 3.8 \\
\hline
\end{tabular}


Table 6. Annual savings per field and annual savings per hectare in each county in scenarios 1,2 , and 3.

\begin{tabular}{|c|c|c|c|c|c|c|}
\hline \multirow[b]{2}{*}{ County } & \multicolumn{3}{|c|}{ Annual Savings per Field (USD) } & \multicolumn{3}{|c|}{ Annual Savings (USD ha ${ }^{-1}$ ) } \\
\hline & $\begin{array}{l}\text { Scenario } 1 \\
\text { (End gun) }\end{array}$ & $\begin{array}{l}\text { Scenario } 2 \\
\text { (Corner } \\
\text { extension) }\end{array}$ & $\begin{array}{c}\text { Scenario } 3 \\
\text { (Corner extension } \\
\text { and end gun) }\end{array}$ & $\begin{array}{l}\text { Scenario } 1 \\
\text { (End gun) }\end{array}$ & $\begin{array}{l}\text { Scenario } 2 \\
\text { (Corner } \\
\text { extension) }\end{array}$ & $\begin{array}{c}\text { Scenario } 3 \\
\text { (Corner extension } \\
\text { and end gun) }\end{array}$ \\
\hline Antelope & 677 & 1454 & 2595 & 13.7 & 29.5 & 52.6 \\
\hline Box Butte & 776 & 1908 & 3737 & 15.7 & 38.7 & 75.7 \\
\hline Butler & 331 & 912 & 1877 & 6.7 & 18.5 & 38.0 \\
\hline Cedar & 862 & 1620 & 2695 & 17.5 & 32.8 & 54.6 \\
\hline Chase & 646 & 1738 & 3486 & 13.1 & 35.2 & 70.7 \\
\hline Custer & 1042 & 2081 & 3461 & 21.1 & 42.2 & 70.1 \\
\hline Hamilton & 370 & 1027 & 2140 & 7.5 & 20.8 & 43.4 \\
\hline Keith & 762 & 1868 & 3616 & 15.4 & 37.9 & 73.3 \\
\hline Phelps & 511 & 1348 & 2718 & 10.4 & 27.3 & 55.1 \\
\hline Thayer & 401 & 1006 & 2023 & 8.1 & 20.4 & 41.0 \\
\hline
\end{tabular}

Table 7. Available investment amount that could be spent on a variablefrequency drive for each county in scenarios 1,2 , and 3.

\begin{tabular}{cccc}
\hline & \multicolumn{3}{c}{ Available Investment Amount (USD) } \\
\cline { 2 - 4 } County & $\begin{array}{c}\text { Scenario 1 } \\
\text { (End gun) }\end{array}$ & $\begin{array}{c}\text { Scenario 3 } \\
\text { (Corner } \\
\text { extension) }\end{array}$ & $\begin{array}{c}\text { Corner extension } \\
\text { and end gun) }\end{array}$ \\
\hline Antelope & 6169 & 13242 & 23637 \\
Box Butte & 7073 & 17383 & 34045 \\
Butler & 3017 & 8307 & 17102 \\
Cedar & 7855 & 14757 & 24554 \\
Chase & 5888 & 15832 & 31761 \\
Custer & 9492 & 18959 & 31529 \\
Hamilton & 3372 & 9357 & 19496 \\
Keith & 6939 & 17016 & 32946 \\
Phelps & 4654 & 12277 & 24761 \\
Thayer & 3652 & 9162 & 18433 \\
\hline
\end{tabular}

In scenario 2, several counties could profitably invest in a VFD. However, in scenario 3, all the counties generated sufficient pumping cost savings to pay back the cost of a VFD within 11 years. Almost a two-fold increase in the county averaged capital investment amounts was calculated with the shift from scenario 2 to scenario 3 . As previously discussed, a major cause for the increase in savings when using a VFD (approach 2) in scenario 3 can be attributed to the pump design based on an end gun that operates for only $10 \%$ each revolution.

\section{Payback Periods}

The average payback periods for each county were calculated using the average annual savings resulting from the energy reductions due to installation of a VFD on 100 center pivots in that specific county. An interest rate of $7 \%$ was used in determining the number of years required to pay back a loan sufficient to purchase a VFD, and those paybacks periods are presented in table 8 . The payback period was taken as the total cost of the installation divided by the annual savings presented in table 6 .

In scenario 1 , the average payback periods were greater than the expected life of the VFD in nearly all counties. Only Cedar and Custer Counties resulted in average payback periods of less than 15 years. Because these are mean values, each installation should be evaluated separately to ensure that purchasing a VFD is an economically sound decision. Even in counties with relatively long payback periods, some field sites would produce sufficient savings to make the purchase. In scenario 2, the purchase of a VFD was economical in all but three counties. In scenario 3, analysis for all counties resulted in payback periods that were less than the estimated economic life of a VFD (table 8).
Table 8. Average payback periods required in each county for scenarios 1,2 , and 3 .

\begin{tabular}{cccc}
\hline & \multicolumn{3}{c}{ Average Payback Period (years) } \\
\cline { 2 - 4 } County & $\begin{array}{c}\text { Scenario 1 } \\
\text { (End gun) }\end{array}$ & $\begin{array}{c}\text { Scenario 2 } \\
\text { (Corner } \\
\text { extension) }\end{array}$ & $\begin{array}{c}\text { Scenario 3 } \\
\text { (Corner extension } \\
\text { and end gun) }\end{array}$ \\
\hline Antelope & 18 & 11 & 8 \\
Box Butte & 15 & 8 & 5 \\
Butler & 36 & 18 & 11 \\
Cedar & 14 & 10 & 7 \\
Chase & 19 & 9 & 6 \\
Custer & 12 & 8 & 6 \\
Hamilton & 32 & 16 & 9 \\
Keith & 16 & 9 & 6 \\
Phelps & 23 & 12 & 7 \\
Thayer & 30 & 16 & 10 \\
\hline
\end{tabular}

\section{SuMmARY AND CONCLUSIONS}

In this study, the use of VFDs to vary pump speed based on the required pivot point pressure was discussed in comparison to using a constant pump speed for 1000 center-pivot sites in ten counties across Nebraska. A standard centerpivot design was used at each site, and digital elevation maps were used to determine the pressure required in $1^{\circ}$ increments for a full pivot rotation. The center-pivot systems were equipped with corner watering attachments, including an end gun (scenario 1), corner extension (scenario 2), and corner extension plus an end gun (scenario 3). Each attachment was sized and operated using standard industry protocol. Pump impellers were selected to meet the flow rate and pressure conditions at peak impeller efficiency. Water application costs were calculated based on county-based depth to groundwater, sprinkler pressure requirements, elevation changes, friction losses, statewide average electric power costs, and net irrigation requirements. Energy use requirements and pumping costs were calculated for constant-speed pump installations (approach 1) and compared with variablespeed pump installations (approach 2).

Cedar County showed the greatest average annual energy use reduction of $16 \%, 23 \%$, and $32 \%$ in scenarios 1,2 , and 3 , respectively. These energy reductions were a function of elevation differences within the field as well as the behavior of the pump performance curve. However, savings in electrical energy $(\mathrm{kWh})$ and in economic terms (dollars) were greatest in Custer County for scenarios 1 and 2 and in Box Butte County for scenario 3 due to the greater number of irrigation hours required in west central Nebraska. Hamilton and Butler Counties exhibited the least average annual energy use as well as monetary savings ( $\mathrm{kWh}$ and dollars) due 
to less topographical changes and the least irrigation hours.

The average annual energy savings per hectare of irrigated area was used to calculate available investment and payback periods for each installation and scenarios 1, 2, and 3. The payback periods calculated in this study were greater than the expected VFD life in scenario 1 but decreased with an increase in irrigation hours as well as with the number of corner attachments (scenarios 2 and 3). Producers with center-pivot systems equipped with corner extensions (scenario 2) and with corner extensions and end guns (scenario 3) can generate economic return on their investments in VFDs. Field sites with significant topographic features and extensive operating hours should consider installing VFDs to alter pump speed based on the actual pressure required by the system.

Although not a topic of this research, the pump characteristic curve will impact the energy use reductions experienced by center-pivot installations equipped with VFDs. For this research, and based on standard engineering design, different impellers were used for scenarios 1, 2, and 3. Steep pump characteristic curves can lead to the greatest energy use reduction due to the rapid change in pressure in relation to the changes in flow rate. Pump curves that are relatively flat over a broad range of flow rates will result in less energy savings overall. Thus, the cost savings experienced for a specific installation will vary depending on the impeller installed in the well.

The decision to use VFDs rather than constant-speed pumps should consider the service life of other components of the water distribution system. For example, because VFDs have a ramp-up speed setting, consideration should be given to the impact that a reduction in pressure surges might have on the diaphragm valves that control sprinkler operation, including pressure regulators. Further, water application uniformity may be affected when the pumping water level drops during the irrigation period. Water application uniformity depends on delivering the correct pressure and flow rate to each sprinkler, and VFDs have a role to play. Variable-rate irrigation systems include valving to pulse groups of sprinklers on an off, and the impact of the resulting variation in flow rate on system operation in relation to the use of VFDs remains to be evaluated. Finally, the use of VFDs might impact the service life of the power supply. These factors remain to be determined, and they justify further research.

Overall, this research indicates that the use of VFDs can provide significant savings in terms of energy conservation and economic benefits for center pivots equipped with corner attachments. However, there are concerns about the costeffectiveness for some installations that were identified by the economic analysis performed in this study. VFDs require initial investment capital that may not be repaid in all cases. Nevertheless, the payback period can be shortened through efforts to reduce the initial investment cost or the increases in power costs. It is expected that VFD technology will receive broad-based adoption if manufacturers are able to address the economic concerns of the end users.

\section{REFERENCES}

Anwar, A. A. (2000). Correction factors for center-pivots with end guns. J. Irrig. Drain. Eng., 126(2), 113-118. https://doi.org/10.1061/(ASCE)0733-9437(2000)126:2(113)

Brar, D., Kranz, W. L., Lo, T. H., Irmak, S., \& Martin, D. L. (2017). Energy conservation using variable-frequency drives for centerpivot irrigation: Standard systems. Trans. ASABE, 60(1), 95106. https://doi.org/10.13031/trans. 11683

Buttermore, G. W., \& Eisenhauer, D. E. (1989). Calculation of chemical flushing times in center-pivot irrigation systems. Trans. ASAE, 32(4), 1193-1196. https://doi.org/10.13031/2013.31133

Chu, S. T., \& Moe, D. L. (1972). Hydraulics of a center-pivot system. Trans. ASAE, 15(5), 894-896. https://doi.org/10.13031/2013.38034

Davis, J. E., Zielke, T. L., \& Coash, R. J. (1986). Corner watering system for center-pivot irrigation machines. U.S. Patent No. $4,569,481 \mathrm{~A}$.

Edling, R. J. (1982). Influence of center-pivot corner irrigation on system performance. Proc. Irrig. Assoc. Conf. (pp. 197-210). St. Joseph, MI: ASAE.

Keller, J., \& Bliesner, R. D. (1990). Sprinkle and trickle irrigation. New York, NY: Van Nostrand Reinhold.

NDNR. (2006). Net irrigation requirement. Lincoln, NE: Nebraska Department of Natural Resources. Retrieved from http://www.dnr.ne.gov/swr/net-irrigation-requirement-map-may2006

Reddy, J. M., \& Apolayo, H. (1988). Friction correction factor for center-pivot irrigation systems. J. Irrig. Drain. Eng., 114(1), 183-185. https://doi.org/10.1061/(ASCE)07339437(1988)114:1(183)

Scaloppi, E. J., \& Allen, R. G. (1993a). Hydraulics of irrigation laterals: Comparative analysis. J. Irrig. Drain. Eng., 119(1), 91115. https://doi.org/10.1061/(ASCE)0733-9437(1993)119:1(91)

Scaloppi, E. J., \& Allen, R. G. (1993b). Hydraulics of center-pivot laterals. J. Irrig. Drain. Eng., 119(3), 554-567. https://doi.org/10.1061/(ASCE)0733-9437(1993)119:3(554)

Solomon, K., \& Kodoma, M. (1978). Center-pivot end sprinkler pattern analysis and selection. Trans. ASAE, 21(4), 706-712. https://doi.org/10.13031/2013.35372

USDA-NASS. (2014). Census of agriculture: 2013 Farm and ranch irrigation survey. Washington, DC: USDA National Agricultural Statistics Service.

USGS. (n.d.). USGS 10 meter resolution. National Elevation Dataset for CONUS, Alaska, Hawaii, Puerto Rico, and the U.S. Virgin Islands. Reston, VA: USGS. Retrieved from http://viewer.nationalmap.gov

Valiantzas, J. D., \& Dercas, N. (2005). Hydraulic analysis of multidiameter center-pivot sprinkler laterals. J. Irrig. Drain. Eng., 131(2), 137-146. https://doi.org/10.1061/(ASCE)07339437(2005)131:2(137)

Von Bernuth, R. D. (1977). Economics of center-pivot end guns. ASAE Paper No. 772008. St. Joseph, MI: ASAE.

Von Bernuth, R. D. (1983). Nozzling considerations for center pivots with end guns. Trans. ASAE, 26(2), 419-422. https://doi.org/10.13031/2013.33950 